\title{
Comparative Efficacy of Pre-feeding, Post-feeding and Combined Pre- and Post-feeding of Two Microdoses of a Potentized Homeopathic Drug, Mercurius Solubilis, in Ameliorating Genotoxic Effects Produced by Mercuric Chloride in Mice
}

\author{
Swapna Datta, Surjyo Jyoti Biswas and Anisur Rahman Khuda-Bukhsh \\ Cytogenetics Laboratory, Department of Zoology, University of Kalyani, West Bengal, India
}

\begin{abstract}
Mercury and its derivatives have become an alarming environmental problem, necessitating the search for effective antagonists, including homeopathic drugs, which are generally used in micro doses and are devoid of any palpable side-effects. On the basis of homeopathic similia principle, two potencies of Mercurius solubilis (Merc Sol-30 and Merc Sol-200) were tested by three administrative modes, i.e. prefeeding, post-feeding and combined pre- and post-feeding, for their possible efficacy in ameliorating mercuric chloride-induced genotoxicity in mice. Healthy mice, Mus musculus, were intraperitoneally injected with $0.06 \%$ solution of mercuric chloride at the rate of $1 \mathrm{ml} / 100 \mathrm{~g}$ of body weight, and assessed for genotoxic effects through conventional endpoints. i.e. chromosome aberrations, micronuclei, mitotic index and sperm head abnormality, keeping suitable controls. Mercuric chloride-treated mice were divided into three sub-groups, which were orally administered with the drug prior to, after and both prior to and after injection of mercuric chloride, and their genotoxic effects were analysed at specific intervals of fixation. Mercuric chloride treatment generally produced more chromosome aberations, micronuclei and sperm head anomaly in mice, but the mitotic index appeared to be slightly reduced. While chromosome aberations, micronuclei and sperm head anomaly were generally reduced in the drug-fed series, the mitotic index showed an apparent increase. In most cases, the combined pre- and post-feeding mode appeared to show the maximum amelioration, followed by post-feeding and prefeeding, in that order. The amelioration by Merc Sol-200 appeared to be slightly more pronounced. We conclude that potentized homeopathic drugs can serve as possible anti-genotoxic agents against specific environmental mutagens, including toxic heavy metals.
\end{abstract}

Keywords: antimutagenesis - environmental pollution - remedy - ultra-low doses

\section{Introduction}

In continuation to a series of works on the efficacy of a potentized homeopathic drug, Arsenicum album, in the amelioration of arsenic-induced toxicity in mice (1-8), we felt the necessity of testing the efficacy of a potentized homeopathic drug,

For reprints and all correspondence: Anisur Rahman Khuda-Bukhsh, Cytogenetics Laboratory, Department of Zoology, University of Kalyani, Kalyani-741 235, West Bengal, India. Tel: +91 33 25828750;

Fax: +91 33 25828282; Res phone no. +91 33 25828768;

E-mail: khudabukhsh_48@ rediffmail.com
Mercurius solubilis, derived from a salt of mercury, Mercurius solubilis Hahnemanni (a precipitation of mercurous-ammonium-nitrate complex) in ameliorating mercuric chlorideinduced genotoxicity in mice as well. In recent years mercury poisoning has assumed an alarming proportion in the environment, and a search for effective antagonists of mercury has already begun. Exposure to mercury salts, carried to various water bodies as run-offs or factory effluent, has been the source of accumulation of this poisonous metal and its salts in fish inhabiting polluted water, endangering the people who may consume them. Methyl mercury-induced chromosomal

The online version of this article has been published under an open access model. Users are entitled to use, reproduce, disseminate, or display the open access version of this article provided that: the original authorship is properly and fully attributed; the Journal and Oxford University Press are attributed as the original place of publication with the correct citation details given; if an article is subsequently reproduced or disseminated not in its entirety but only in part or as a derivative work this must be clearly indicated. 
damages have been reported in lymphocyte culture (9) of 23 persons who ingested fish exposed to mercury-contaminated water. Even accidental exposure to mercury, e.g. in 1965 at Minamata and Niigata in Japan, has been shown to cause considerable genotoxic damage, directly or indirectly, to human beings, noticeable even in successive generations. Similarly, the detrimental effects of mercury on cellular systems in different mammals have been well-documented (10). Influence of mercury intoxication has also been studied in rat hepatic microsomal proteins (11) and the cytogenetic effects of methyl mercury have been reviewed by Ramel $(12,13)$. Further, mixtures of cadmium chloride and mercuric chloride have also been reported to enhance cytotoxic effects in rat hepatocyte culture cells (14). However, there has been no documented earlier attempt to test the efficacy of any potentized homeopathic drug for the potential ability to reduce mercury-induced genotoxicity. Therefore, the present investigation was undertaken to evaluate the relative efficacy, if any, of two microdoses of the homeopathic drug Mercurius solubilis (namely, Merc Sol-30 and Merc Sol-200) in ameliorating mercury-induced genotoxicity in mice. Further, the relative efficacy of three modes of administration, i.e. pre-feeding, post-feeding and combined pre- and post-feeding, for each potency has also been evaluated.

\section{Materials and Methods}

\section{Mice}

Inbred lines of mice (Mus musculus), cultured and maintained on an artificial standard diet and water ad libitum (under the supervision of the animal welfare committee, University of Kalyani), were used for the present study. Generally, 3-4-months-old healthy adult mice of both sexes weighing 22-28 g were selected for the study.

\section{Treatment of Test Chemical}

After a brief range-finding trial, $0.006 \%$ solution of mercuric chloride $(6 \mathrm{mg}$ dissolved in $100 \mathrm{ml}$ of distilled water) was found to be a mild sub-lethal dose, which was enough for producing quantifiable genotoxic effects. Therefore, this dose was intra-peritoneally pushed into mice through a single injection at the rate of $1 \mathrm{ml} / 100 \mathrm{~g}$ of body weight. Injected mice were divided into two groups: (i) those fed the diluted homeopathic drug in either potency, and (ii) those fed diluted succussed alcohol (i.e. Alc-30 or Alc-200), which served as positive controls. A third group of normal healthy mice, which were not injected with mercuric chloride, served as the negative controls. Another set of negative controls was maintained with mice not injected with mercuric chloride, but fed with either potency of the homeopathic drug, to examine if the homeopathic drug fed to normal healthy mice produced any genotoxic effects in them. Mice were sacrificed at six intervals of fixation: $6,12,24,48,72$ and $96 \mathrm{~h}$ after mercury treatment. Five mice were used for each of the drug-fed $(\mathrm{T})$ and control $(\mathrm{C})$ series at each fixation period.

\section{Preparation of Homeopathic Stock Solution and Feeding Procedure}

Aliquots (0.06 $\mathrm{ml}$ each) of the homeopathic drugs, Merc Sol-30 and Merc Sol-200 (procured from HAPCO, 165, Bipin Behari Ganguli Street, Kolkata) were diluted separately with $20 \mathrm{ml}$ of distilled water (normal practice for human subjects), which formed the stock solution of the drug, Merc Sol30 and Merc Sol-200, respectively. Samples of $0.06 \mathrm{ml}$ of the stock solution (this dilution was made due to the size difference between mice and humans) were orally fed to mice with the aid of a special pipette (three times a day for Merc Sol-30, i.e. at $6 \mathrm{am}, 12$ noon and $6 \mathrm{pm}$, and twice daily for Merc Sol-200, i.e. at 6 am and $6 \mathrm{pm}$, until sacrifice). Similarly, $0.06 \mathrm{ml}$ of succussed alcohol (Alc-30 or Alc-200) was diluted with $20 \mathrm{ml}$ of distilled water to make the stock solution of alcohol. Again, $0.06 \mathrm{ml}$ of succussed alcohol was similarly fed orally to the control sets of mice at the corresponding times of drug-feeding.

\section{Cytogenetic Methods}

The standard cytogenetic protocols, i.e. assays of chromosome aberrations, micronuclei, mitotic index and sperm head anomaly were adopted in the present study to determine the genotoxic effects.

\section{Chromosome Preparation and Scoring of Chromosome Aberations}

Mice were intra-peritoneally injected with $0.025 \%$ colchicine at a dose of $1 \mathrm{ml} / 100 \mathrm{~g}$ body weight $90 \mathrm{~min}$ before sacrifice. Marrow of the femur was flushed in $1 \%$ sodium citrate solution at $37^{\circ} \mathrm{C}$ and fixed in acetic acid/ethanol (1:3). Slides were prepared by the conventional flame drying technique followed by Giemsa staining for scoring bone marrow chromosome aberations. Chromosome aberations of various nature have been pooled into two categories: the 'major' type comprising aberrations like break, fragments, ring, polyploidy etc. and the 'other' types comprising less significant aberrations like gaps, erosions, precocious centromeric separation, pycnosis, stretching etc. However, the combined frequency of both major and other type aberrations only has been shown for each of the different series. A total of 500 bone marrow cells were observed, taking about 100 from each of the five mice of a set for each fixation interval.

\section{Micronuclei Study and Determination of Mitotic Index}

For micronuclei preparation, a part of the suspension of bone marrow cells in $1 \%$ sodium citrate was smeared on clean grease-free slides, briefly fixed in methanol and subsequently stained with May-Grunwald followed by Giemsa. Approximately 5000 bone marrow cells, comprising both polychromatic erythrocytes (PCE) and normochromatic erythrocytes (NCE) were scored, and the combined frequency of both types only are shown in the tables. 
The mitotic index was assessed from the same slide, which was scanned for micronuclei. The non-dividing and dividing cells were recorded and their ratios calculated.

\section{Sperm Head Anomaly Study}

For sperm head anomaly, the technique of Wyrobek et al. (15) was adopted with minor modifications. Epididymis from each side of testis of control or treated sets of mice was dissected out and the inner content squeezed out into $10 \mathrm{ml}$ of $0.87 \%$ normal saline separately. It was made free of fats, vas deferens and other tissues. The content was thoroughly shaken, filtered through a silken cloth and dropped on grease-free clean slides. The slides were allowed to air dry and then stained by dilute Giemsa (1 ml Giemsa in $10 \mathrm{ml}$ distilled water).

\section{Statistical Analysis and Scoring of Data}

The observers were 'blinded' as to whether the slides they were examining were from a treated or control series.
Students' t-test was conducted as per standard procedure for determining the significance level of the differences between treated and control data.

\section{Results}

\section{Controls}

Firstly, the cytogenetic data in the group of healthy mice fed with either potency of the homeopathic drug alone at the specified time intervals revealed that there was hardly any elevation in the frequency of aberrations, micronuclei or sperm head anomaly, as compared to normal mice either not receiving drug at all or only receiving dilute succussed alcohol (being the vehicle of the drug). In fact the mice of both positive (only drug-fed) and negative controls (drug-unfed healthy mice) revealed negligible cytogenetic abnormalities (within the range of spontaneous abnormalities). Therefore, the data for one normal control only have been incorporated in Tables $1-3$ and

Table 1. Frequency distribution of mitotic index, chromosome aberations, micronuclei, and sperm head anomaly in mice at different fixation intervals in pre-fed mercuric chloride-treated mice

\begin{tabular}{|c|c|c|c|c|c|c|c|c|c|}
\hline \multirow{2}{*}{$\begin{array}{l}\text { Fixation interval } \\
\text { (h) }\end{array}$} & \multirow[t]{2}{*}{ Series } & \multicolumn{2}{|c|}{ Mitotic index } & \multicolumn{2}{|c|}{ Chromosome aberations } & \multicolumn{2}{|c|}{ Micronucleated erythrocytes } & \multicolumn{2}{|c|}{ Sperm head anomaly } \\
\hline & & $\%( \pm \mathrm{SE})$ & $\%$ increase & Total $(\% \pm \mathrm{SE})$ & $\%$ Suppr & Total $(\% \pm \mathrm{SE})$ & $\%$ Suppr & Total $(\% \pm \mathrm{SE})$ & $\%$ Suppr \\
\hline \multicolumn{10}{|c|}{ Pre-fed with Merc Sol-30 $\left(\mathrm{T}_{1}\right)$ and Alc-30 $\left(\mathrm{C}_{1}\right)$} \\
\hline \multirow[t]{2}{*}{6} & $\mathrm{~T}_{1}$ & $1.50 \pm 0.11$ & 0.04 & $11.80 \pm 1.14$ & 10.6 & & & $1.12 \pm 0.29$ & 0.00 \\
\hline & $\mathrm{C}_{1}$ & $1.46 \pm 0.17$ & & $13.20 \pm 1.38$ & & & & $1.12 \pm 0.28$ & \\
\hline \multirow[t]{2}{*}{12} & $\mathrm{~T}_{1}$ & $1.54 \pm 0.11$ & $0.56^{* *}$ & $16.80 \pm 2.04$ & $(-)$ & $0.41 \pm 0.04$ & 22.6 & $2.22 \pm 0.19$ & $(-)$ \\
\hline & $\mathrm{C}_{1}$ & $0.98 \pm 0.07$ & & $15.60 \pm 1.64$ & & $0.53 \pm 0.04$ & & $1.72 \pm 0.24$ & \\
\hline \multirow[t]{2}{*}{24} & $\mathrm{~T}_{1}$ & $1.36 \pm 0.09$ & $0.36^{*}$ & $26.20 \pm 2.07$ & 12.08 & $0.27 \pm 0.04$ & $69.6 * * *$ & $5.16 \pm 0.37$ & $29.12 *$ \\
\hline & $\mathrm{C}_{1}$ & $1.00 \pm 0.07$ & & $29.80 \pm 1.74$ & & $0.89 \pm 0.07$ & & $7.28 \pm 0.67$ & \\
\hline \multirow[t]{2}{*}{48} & $\mathrm{~T}_{1}$ & $0.86 \pm 0.13$ & 0.10 & $31.80 \pm 1.81$ & 14.9 & $0.23 \pm 0.02$ & $75.2 * *$ & $4.60 \pm 0.16$ & 9.8 \\
\hline & $\mathrm{C}_{1}$ & $0.76 \pm 0.10$ & & $37.40 \pm 2.33$ & & $0.93 \pm 0.05$ & & $5.10 \pm 0.35$ & \\
\hline \multirow[t]{2}{*}{72} & $\mathrm{~T}_{1}$ & $1.26 \pm 0.16$ & 0.26 & $22.40 \pm 1.60$ & $21.1^{*}$ & $0.49 \pm 0.05$ & $49.4 * * *$ & $2.60 \pm 0.20$ & 19.2 \\
\hline & $\mathrm{C}_{1}$ & $1.00 \pm 0.12$ & & $28.40 \pm 1.68$ & & $0.97 \pm 0.08$ & & $3.22 \pm 0.31$ & \\
\hline \multirow[t]{2}{*}{96} & $\mathrm{~T}_{1}$ & $1.56 \pm 0.34$ & 0.12 & $17.60 \pm 1.15$ & $27.8 * *$ & $0.47 \pm 0.70$ & $61.4 * * *$ & $1.52 \pm 0.22$ & $49.3 * * *$ \\
\hline & $\mathrm{C}_{1}$ & $1.44 \pm 0.26$ & & $24.40 \pm 1.60$ & & $1.22 \pm 0.08$ & & $3.00 \pm 0.21$ & \\
\hline \multicolumn{10}{|c|}{ Pre-fed with Merc Sol-200 (T $\left.T_{1}\right)$ and Alc-200 $\left(\mathrm{C}_{1}\right)$} \\
\hline \multirow[t]{2}{*}{6} & $\mathrm{~T}_{1}$ & $1.56 \pm 0.14$ & 0.06 & $12.60 \pm 0.97$ & 8.6 & & & $1.08 \pm 0.26$ & 3.57 \\
\hline & $\mathrm{C}_{1}$ & $1.50 \pm 0.18$ & & $13.80 \pm 1.43$ & & & & $1.12 \pm 0.28$ & \\
\hline \multirow[t]{2}{*}{12} & $\mathrm{~T}_{1}$ & $1.72 \pm 0.13$ & $0.78 * * *$ & $16.00 \pm 2.15$ & 2.4 & $0.33 \pm 0.05$ & $42.1 *$ & $2.44 \pm 0.19$ & $(-)$ \\
\hline & $\mathrm{C}_{1}$ & $0.94 \pm 0.05$ & & $16.40 \pm 2.01$ & & $0.57 \pm 0.09$ & & $1.84 \pm 0.19$ & \\
\hline \multirow[t]{2}{*}{24} & $\mathrm{~T}_{1}$ & $1.52 \pm 0.08$ & $0.48 * * *$ & $27.40 \pm 1.98$ & 11.0 & $0.31 \pm 0.05$ & $68.0^{* * *}$ & $4.90 \pm 0.29$ & $34.6 * *$ \\
\hline & $\mathrm{C}_{1}$ & $1.04 \pm 0.11$ & & $30.80 \pm 2.04$ & & $0.97 \pm 0.06$ & & $7.50 \pm 0.62$ & \\
\hline \multirow[t]{2}{*}{48} & $\mathrm{~T}_{1}$ & $1.08 \pm 0.18$ & $0.38 *$ & $31.00 \pm 2.71$ & 17.5 & $0.27 \pm 0.05$ & $73.7 * * *$ & $3.74 \pm 0.29$ & $28.3^{*}$ \\
\hline & $\mathrm{C}_{1}$ & $0.70 \pm 0.10$ & & $37.60 \pm 2.65$ & & $1.03 \pm 0.02$ & & $5.22 \pm 0.40$ & \\
\hline \multirow[t]{2}{*}{72} & $\mathrm{~T}_{1}$ & $1.54 \pm 0.14$ & $0.58 *$ & $21.20 \pm 1.29$ & $25.3 * *$ & $0.61 \pm 0.07$ & $44.5^{* *}$ & $3.10 \pm 0.23$ & $(-)$ \\
\hline & $\mathrm{C}_{1}$ & $0.96 \pm 0.14$ & & $28.40 \pm 1.30$ & & $1.10 \pm 0.09$ & & $2.26 \pm 0.14$ & \\
\hline \multirow[t]{3}{*}{96} & $\mathrm{~T}_{1}$ & $1.98 \pm 0.18$ & 0.62 & $16.20 \pm 1.38$ & $36.2 * *$ & $0.59 \pm 0.06$ & $52.4 * * *$ & $1.42 \pm 0.12$ & $54.1 * * *$ \\
\hline & $\mathrm{C}_{1}$ & $1.36 \pm 0.23$ & & $25.40 \pm 1.30$ & & $1.24 \pm 0.08$ & & $3.10 \pm 0.23$ & \\
\hline & $\mathrm{N}$ & $1.40 \pm 0.06$ & & $1.47 \pm 0.23$ & & $0.14 \pm 0.05$ & & $0.69 \pm 0.11$ & \\
\hline
\end{tabular}

Suppr, Suppression; N, normal control.

$* P<0.05$; ** $P<0.01$; *** $P<0.001$. 
Table 2. Frequency distribution of mitotic index, chromosome aberations, micronuclei, and sperm head anomaly in mice at different fixation intervals in post-fed mercuric chloride-treated mice

\begin{tabular}{|c|c|c|c|c|c|c|c|c|c|}
\hline \multirow{2}{*}{$\begin{array}{l}\text { Fixation interval } \\
\text { (h) }\end{array}$} & \multirow[t]{2}{*}{ Series } & \multicolumn{2}{|c|}{ Mitotic index } & \multicolumn{2}{|c|}{ Chromosome aberations } & \multicolumn{2}{|c|}{ Micronucleated erythrocytes } & \multicolumn{2}{|c|}{ Sperm head anomaly } \\
\hline & & $\%(\% \pm \mathrm{SE})$ & $\%$ increase & Total $(\% \pm \mathrm{SE})$ & $\%$ Suppr & Total $(\% \pm \mathrm{SE})$ & $\%$ Suppr & Total $(\% \pm \mathrm{SE})$ & $\%$ Suppr \\
\hline \multicolumn{10}{|c|}{ Post-fed with Merc Sol-30 $\left(\mathrm{T}_{2}\right)$ and Alc-30 $\left(\mathrm{C}_{2}\right)$} \\
\hline 6 & $\mathrm{C}_{2}$ & $1.32 \pm 0.28$ & & $14.60 \pm 1.60$ & & & & $0.96 \pm 0.21$ & \\
\hline \multirow[t]{2}{*}{12} & $\mathrm{~T}_{2}$ & $1.76 \pm 0.09$ & $0.68 * * *$ & $12.00 \pm 2.00$ & 31.0 & $0.35 \pm 0.05$ & 28.5 & $1.74 \pm 0.16$ & 17.9 \\
\hline & $\mathrm{C}_{2}$ & $1.08 \pm 0.10$ & & $17.40 \pm 2.30$ & & $0.49 \pm 0.06$ & & $2.12 \pm 0.23$ & \\
\hline 24 & $\mathrm{C}_{2}$ & $1.20 \pm 0.11$ & & $30.00 \pm 2.13$ & & $0.82 \pm 0.09$ & & $7.14 \pm 0.47$ & \\
\hline \multirow[t]{2}{*}{48} & $\mathrm{~T}_{2}$ & $1.22 \pm 0.13$ & $0.74 * *$ & $23.40 \pm 2.48$ & $41.8 * *$ & $0.59 \pm 0.07$ & $42.7 *$ & $3.76 \pm 0.17$ & 26.8 \\
\hline & $\mathrm{C}_{2}$ & $0.48 \pm 0.09$ & & $40.20 \pm 3.89$ & & $1.03 \pm 0.10$ & & $5.14 \pm 0.66$ & \\
\hline \multirow[t]{2}{*}{72} & $\mathrm{~T}_{2}$ & $1.86 \pm 0.13$ & $0.86^{* *}$ & $19.20 \pm 2.48$ & $39.6^{* *}$ & $0.61 \pm 0.09$ & $41.9^{*}$ & $2.26 \pm 0.27$ & 23.6 \\
\hline & $\mathrm{C}_{2}$ & $1.00 \pm 0.13$ & & $31.80 \pm 2.48$ & & $1.05 \pm 0.11$ & & $2.96 \pm 0.20$ & \\
\hline \multirow[t]{2}{*}{6} & $\mathrm{~T}_{2}$ & $1.68 \pm 0.11$ & 0.26 & $9.60 \pm 0.83$ & $27.2^{*}$ & & & $0.54 \pm 0.08$ & 51.7 \\
\hline & $\mathrm{C}_{2}$ & $1.42 \pm 0.16$ & & $13.20 \pm 1.20$ & & & & $1.12 \pm 0.34$ & \\
\hline \multirow[t]{2}{*}{12} & $\mathrm{~T}_{2}$ & $1.94 \pm 0.13$ & $0.96^{* * *}$ & $8.40 \pm 1.03$ & $47.5^{* *}$ & $0.27 \pm 0.04$ & $50.9 * *$ & $2.38 \pm 0.19$ & $(-)$ \\
\hline & $\mathrm{C}_{2}$ & $0.98 \pm 0.10$ & & $16.00 \pm 2.17$ & & $0.55 \pm 0.05$ & & $1.92 \pm 0.23$ & \\
\hline \multirow[t]{2}{*}{24} & $\mathrm{~T}_{2}$ & $1.70 \pm 0.11$ & $0.58 * *$ & $22.80 \pm 1.78$ & $22.9^{*}$ & $0.49 \pm 0.07$ & $48.4 * *$ & $3.90 \pm 0.29$ & $47.8^{*}$ \\
\hline & $\mathrm{C}_{2}$ & $1.12 \pm 0.09$ & & $29.60 \pm 1.92$ & & $0.95 \pm 0.10$ & & $7.48 \pm 1.04$ & \\
\hline \multirow[t]{2}{*}{48} & $\mathrm{~T}_{2}$ & $1.36 \pm 0.16$ & $0.76 * *$ & $18.00 \pm 0.98$ & $52.8 * * *$ & $0.43 \pm 0.05$ & 5.7 & $3.28 \pm 0.30$ & $39.4 * *$ \\
\hline & $\mathrm{C}_{2}$ & $0.60 \pm 0.07$ & & $38.20 \pm 2.88$ & & $1.00 \pm 0.05$ & & $5.42 \pm 0.48$ & \\
\hline \multirow[t]{2}{*}{72} & $\mathrm{~T}_{2}$ & $1.94 \pm 0.29$ & $0.94 *$ & $19.00 \pm 2.29$ & $35.8^{* * * *}$ & $0.49 \pm 0.06$ & $57.01 * * *$ & $1.92 \pm 0.15$ & $34.6^{*}$ \\
\hline & $\mathrm{C}_{2}$ & $1.00 \pm 0.13$ & & $29.60 \pm 1.78$ & & $1.14 \pm 0.11$ & & $2.94 \pm 0.32$ & \\
\hline
\end{tabular}

Suppr, Suppression; N, normal control.

$* P<0.05 ; * * P<0.01 ; * * * P<0.001$.

Figures 2-7 for reasons of economy of space and clarity of purpose. On the other hand, relevant data between the drug-fed and succussed alcohol-fed (e.g. Alc-30- or Alc-200-fed) mice treated with mercuric chloride were focused more to assess the quantum of modulation that could be attributed to the feeding of the specific potency of drug at a particular fixation interval.

In mice treated with mercuric chloride, there were distinct elevations in the frequency of the cytogenetic parameters studied and in mice fed with either potency of Merc Sol, before (Figs 2 and 3) or after (Figs 4 and 5), or both before and after (Figs 6 and 7), definite modulations with respect to all the parameters examined could be evidenced.

While in normal healthy control mice, the total frequencies of chromosome aberrations, micronuclei and sperm head abnormality were $1.47 \%, 0.14 \%$ and $0.69 \%$, respectively, these were considerably enhanced in the mercuric chloridetreated mice at all intervals of fixation (Tables 1-3, Figs 2-7). However, the percentages of mitotic index in the mercuric chloride-treated mice were generally reduced to a varying extent as compared to the $1.4 \%$ found in normal healthy mice. While the mitotic index was generally increased in the drugfed series, to a different extent in the three modes of feeding, the chromosome aberations (Fig. 1A-F), micronuclei (Fig. 1G and $\mathrm{H}$ ) and sperm head anomaly (Fig. 1K-O) frequencies were considerably reduced in the drug-fed series, the maximum efficacy being found in the combined pre-and postfed series, followed by post-fed, then pre-fed series, in that order (Tables 1-3, Figs 2-7).

\section{Pre-feeding}

In the mercuric chloride-treated mice the mitotic indices were found to be reduced at $12 \mathrm{~h}$ onwards up to $72 \mathrm{~h}$, after which the mitotic index was apparently restored to normal levels. In both Merc Sol-30- and Merc Sol-200-fed mice the mitotic indices were found to be elevated right from $6 \mathrm{~h}$ through to $96 \mathrm{~h}$, the Merc Sol-200 showing a little more mitotic index enhancing ability than Merc Sol-30 (Table 1, Figs 2 and 3). 
Table 3. Frequency distribution of mitotic index, chromosome aberations, micronuclei, and sperm head anomaly in mice at different fixation intervals in pre- and post-fed mercuric chloride-treated mice

\begin{tabular}{|c|c|c|c|c|c|c|c|c|c|}
\hline \multirow{2}{*}{$\begin{array}{l}\text { Fixation interval } \\
\text { (h) }\end{array}$} & \multirow[t]{2}{*}{ Series } & \multicolumn{2}{|c|}{ Mitotic index } & \multicolumn{2}{|c|}{ Chromosome aberations } & \multicolumn{2}{|c|}{ Micronucleated erythrocytes } & \multicolumn{2}{|c|}{ Sperm head anomaly } \\
\hline & & $\%(\% \pm \mathrm{SE})$ & $\%$ increase & Total $(\% \pm \mathrm{SE})$ & $\%$ Suppr & Total $(\% \pm \mathrm{SE})$ & $\%$ Suppr & Total $(\% \pm \mathrm{SE})$ & $\%$ Suppr \\
\hline \multicolumn{10}{|c|}{ Pre and post-fed with Merc Sol-30 $\left(\mathrm{T}_{3}\right)$ and Alc-30 $\left(\mathrm{C}_{3}\right)$} \\
\hline 6 & $\mathrm{C}_{3}$ & $1.40 \pm 0.12$ & & $11.40 \pm 1.44$ & & & & $0.52 \pm 0.09$ & \\
\hline \multirow[t]{2}{*}{12} & $\mathrm{~T}_{3}$ & $1.90 \pm 0.13$ & $1.11 * * *$ & $8.40 \pm 1.03$ & 41.7 & $0.33 \pm 0.02$ & $45.9 * *$ & $1.44 \pm 0.35$ & 17.2 \\
\hline & $\mathrm{C}_{3}$ & $0.88 \pm 0.08$ & & $14.40 \pm 2.56$ & & $0.61 \pm 0.06$ & & $1.74 \pm 0.30$ & \\
\hline 24 & $\mathrm{C}_{3}$ & $1.14 \pm 0.08$ & & $27.00 \pm 1.83$ & & $0.73 \pm 0.19$ & & $7.72 \pm 0.39$ & \\
\hline \multirow[t]{2}{*}{48} & $\mathrm{~T}_{3}$ & $1.84 \pm 0.19$ & $1.06^{* * *}$ & $16.20 \pm 1.47$ & $55.0 * * *$ & $0.43 \pm 0.02$ & $62.9 * * *$ & $3.12 \pm 0.27$ & $43.8^{* *}$ \\
\hline & $\mathrm{C}_{3}$ & $0.78 \pm 0.07$ & & $36.00 \pm 3.18$ & & $1.16 \pm 0.09$ & & $5.56 \pm 0.46$ & \\
\hline \multirow[t]{2}{*}{72} & $\mathrm{~T}_{3}$ & $2.08 \pm 0.23$ & $1.10^{* * *}$ & $19.20 \pm 2.38$ & $31.4^{*}$ & $0.61 \pm 0.04$ & $51.5^{* * *}$ & $1.78 \pm 0.07$ & $38.2^{*}$ \\
\hline & $\mathrm{C}_{3}$ & $0.98 \pm 0.15$ & & $28.00 \pm 2.09$ & & $1.26 \pm 0.10$ & & $2.88 \pm 0.34$ & \\
\hline \multirow[t]{2}{*}{6} & $\mathrm{~T}_{3}$ & $1.52 \pm 0.10$ & 0.20 & $7.60 \pm 0.83$ & $36.7^{*}$ & & & $0.40 \pm 0.11$ & 60.8 \\
\hline & $\mathrm{C}_{3}$ & $1.34 \pm 0.13$ & & $12.20 \pm 1.29$ & & & & $1.02 \pm 0.28$ & \\
\hline \multirow[t]{2}{*}{12} & $\mathrm{~T}_{3}$ & $2.14 \pm 0.13$ & $1.42^{* * * *}$ & $6.40 \pm 1.03$ & $56.7 * *$ & $0.23 \pm 0.02$ & $62.3^{* *}$ & $1.34 \pm 0.35$ & 27.0 \\
\hline & $\mathrm{C}_{3}$ & $0.72 \pm 0.17$ & & $14.80 \pm 2.07$ & & $0.61 \pm 0.08$ & & $1.84 \pm 0.25$ & \\
\hline \multirow[t]{2}{*}{24} & $\mathrm{~T}_{3}$ & $2.22 \pm 0.42$ & $1.18^{*}$ & $18.60 \pm 1.92$ & $35.5^{* *}$ & $0.33 \pm 0.05$ & $66.7 * * *$ & $3.32 \pm 0.20$ & $54.2^{* * *}$ \\
\hline & $\mathrm{C}_{3}$ & $1.04 \pm 0.10$ & & $28.80 \pm 1.85$ & & $0.99 \pm 0.10$ & & $7.24 \pm 0.50$ & \\
\hline \multirow[t]{2}{*}{48} & $\mathrm{~T}_{3}$ & $2.10 \pm 0.22$ & $1.38 * * *$ & $13.80 \pm 1.71$ & $63.2 * * *$ & $0.27 \pm 0.02$ & $74.2 * * *$ & $2.80 \pm 0.24$ & $49.3 * * *$ \\
\hline & $\mathrm{C}_{3}$ & $0.72 \pm 0.06$ & & $37.40 \pm 2.86$ & & $1.08 \pm 0.06$ & & $5.52 \pm 0.47$ & \\
\hline \multirow[t]{2}{*}{72} & $\mathrm{~T}_{3}$ & $2.42 \pm 0.28$ & $1.48 * *$ & $16.80 \pm 2.16$ & $40.8^{* *}$ & $0.31 \pm 0.05$ & $73.7 * * *$ & $1.62 \pm 0.13$ & $43.3 * *$ \\
\hline & $\mathrm{C}_{3}$ & $0.94 \pm 0.12$ & & $28.40 \pm 1.75$ & & $1.18 \pm 0.12$ & & $2.86 \pm 0.30$ & \\
\hline
\end{tabular}

Suppr, Suppression; N, normal control.

$* P<0.05 ; * * P<0.01 ; * * * P<0.001$.

As compared to the total frequencies of chromosome aberations $(1.47 \%)$ in the normal healthy control there was a considerable increase in the frequencies of chromosome aberations in the mercuric chloride-treated series at all intervals of fixation. However, a critical analysis of the data revealed that pre-feeding of the drug helped suppression of aberrations to a varying degree at all fixation intervals, except at $12 \mathrm{~h}$ in the Merc Sol-30-fed series (Table 1). However, again the Merc Sol-200 showed a marginally better efficacy vis-à-vis Merc Sol-30 (Figs 2 and 3). As compared to untreated normal healthy mice showing $0.14 \%$ micronuclei, the frequencies of micronuclei in the mercuric chloride-treated mice were invariably enhanced at all intervals of fixation. On the other hand, in the drug-fed series there were suppressions of micronuclei at various fixation intervals, most of which were statistically significant (between $P<0.01$ and $P<0.001$, Table 1). In case of micronuclei (which are generally expected to manifest more after 30 h, i.e. after the completion of first cell cycle) the Merc Sol-30 apparently had a marginally better efficacy.
As compared to $0.69 \%$ sperm showing abnormal head morphology in normal healthy control mice, there was generally an increase in their total frequencies at all intervals of fixation in the mercuric chloride-treated mice. However, the percentages of suppression in the frequencies of abnormal sperm in the drug-fed series was not so pronounced at some fixation intervals, particularly in the Merc Sol-30-fed series (see Table 1), though there was a marginally better efficacy shown by Merc Sol-200.

\section{Post-feeding}

The same trend of a generally lower mitotic index shown in mercuric chloride-treated mice as compared to untreated normal ones and increase in the drug-fed series was also noticed in the post-fed mice (Table 2, Figs 4 and 5). A critical analysis of the data revealed that in the post-fed series the degree of suppression was visibly greater than in the pre-fed series in most of the parameters studied. Further, the degree of 
(a)

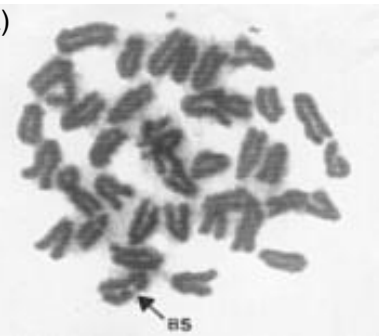

(c)
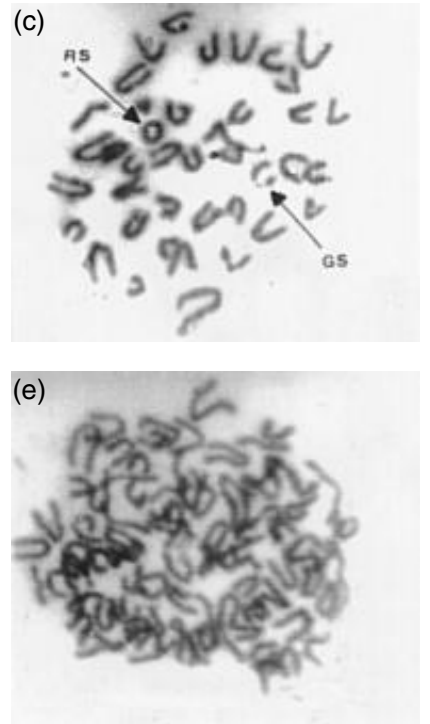

(g)

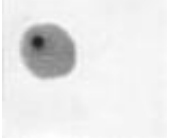

(k)

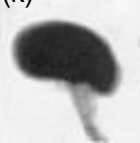

(h)

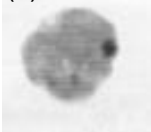

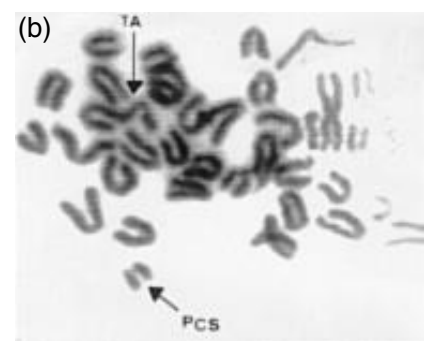

(d)

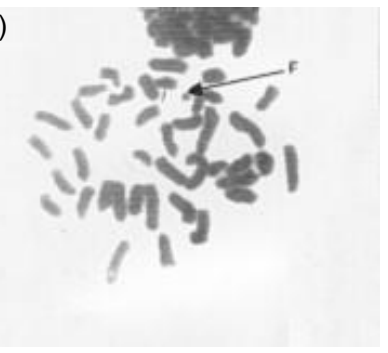

(f)

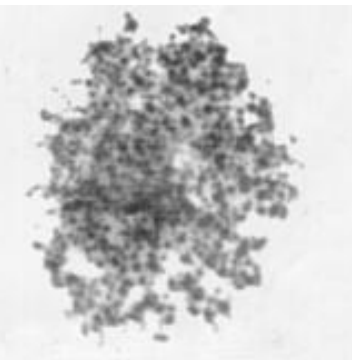

(i)

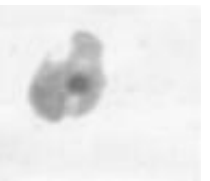

(n)

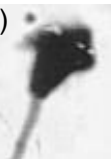

(j)

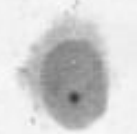

(o)

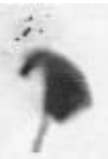

Figure 1. (A-F) Photomicrographs of metaphase complements showing: (A) break (BS); (B) terminal association (TA) and precocious centromeric separation (PCS); (C) ring (RS) and gap (GS); (D) fragment (F); (E) polyploidy; and (F) pulverisation. (G-J) Bone marrow smears showing micronucleated erythrocytes: ( $\mathbf{G}$ and $\mathbf{H})$ polychromatic and (I and $\mathbf{J}$ ) normochromatic erythrocytes. (K-O) Photomicrographs of sperm showing various abnormal head shapes.

amelioration was also marginally better in the Merc Sol-200-fed series as compared to that of the Merc Sol-30-fed series.

\section{Combined Pre- and Post-feeding}

The same trend of a generally lower mitotic index shown in mercuric chloride-treated mice as compared to untreated normal ones and increase in the drug-fed series was also noticed in the combined pre- and post-fed mice. However, on a comparative basis the combined pre- and post-feeding brought forth much more amelioration in terms of the genotoxic parameters studied. Similarly, Merc Sol-200 showed a slightly more pronounced effect, particularly at $96 \mathrm{~h}$, than that of the Merc Sol-30-fed series (Table 3, Figs 6 and 7). On the whole the degree of amelioration provided by pre- and post-feeding of the drug was more pronounced than that of either pre- or post-feeding alone, and the post-feeding mode showed better ameliorative potential than that of pre-feeding alone.

\section{Discussion}

Mercuric chloride is an extremely toxic salt. In the present study, even a single injection at a sub-lethal dose produced genotoxic effects in mice as revealed from the enhanced frequencies of chromosome aberrations, micronuclei in the bone marrow cells and increased frequencies of sperm head abnormality. While the chromosome aberations would provide evidence of damaging effects of mercuric chloride on the genome (hereditary vehicles) of mice, the occurrence of micronuclei also provides an indirect measurement of the induction of structural chromosome aberations. Micronuclei are small chromatin-containing bodies arising from the chromosomes that failed to incorporate into daughter nuclei following mitosis. The genotoxic effects appeared to increase gradually up to $72 \mathrm{~h}$, after which they showed signs of a decline. In keeping with our findings, Kato (16) reported chromosome breakage associated with treatment of organic mercury in Chinese hamster cells in vitro. In earlier studies, mercury and other derivatives of mercury such as phenyl and methyl mercury have also been reported to produce chromosome abnormalities, induce genetic and teratogenic effects and to inhibit spindle formation during mitosis in rats (see 10 for review). Further, Das et al. (17) also demonstrated that mercuric chloride altered DNA and RNA synthesis. Some macro molecular agents such as thiol compounds, selenium, some vitamins, e.g. D and E, and some antioxidants had earlier been reported to have important antagonistic effects to mercury poisoning (10). But this seems to be the first report on the ability of a homeopathic drug to act as an effective antagonist of mercury poisoning. Interestingly, in the present study both the 30th and 200th potencies of Merc Sol, which contained hardly a single original molecule of the drug ingredient (theoretically speaking), appeared to effectively ameliorate the genotoxic effects produced by mercuric chloride. Incidentally, chromosomes are made up mainly of DNA and protein. There is an intrinsic mechanism of repair and retrieval of DNA, under strict genetic control in most organisms, including mice. In mice, specific genes are activated when there is any breakage or insult to DNA by any clastogenic/mutagenic agent (e.g. XPA gene for damage recognition, XPB and XPD for helicase activity, XPC for DNA binding etc.) and a lot of gene activity has been documented (e.g. genes rec A, lex A, uvr A, uvr B, umu $\mathrm{C}$, him $\mathrm{A}$ etc.) for taking corrective measures to repair the damage $(18,19)$. In the present study, repair of chromosome damage has been noted in a steadily enhanced rate in the homeopathic drug-fed mice as compared to that in the mercuric chloride-treated but drug-unfed mice. Therefore, one hypothesis to explain the ability of the potentized homeopathic drug 


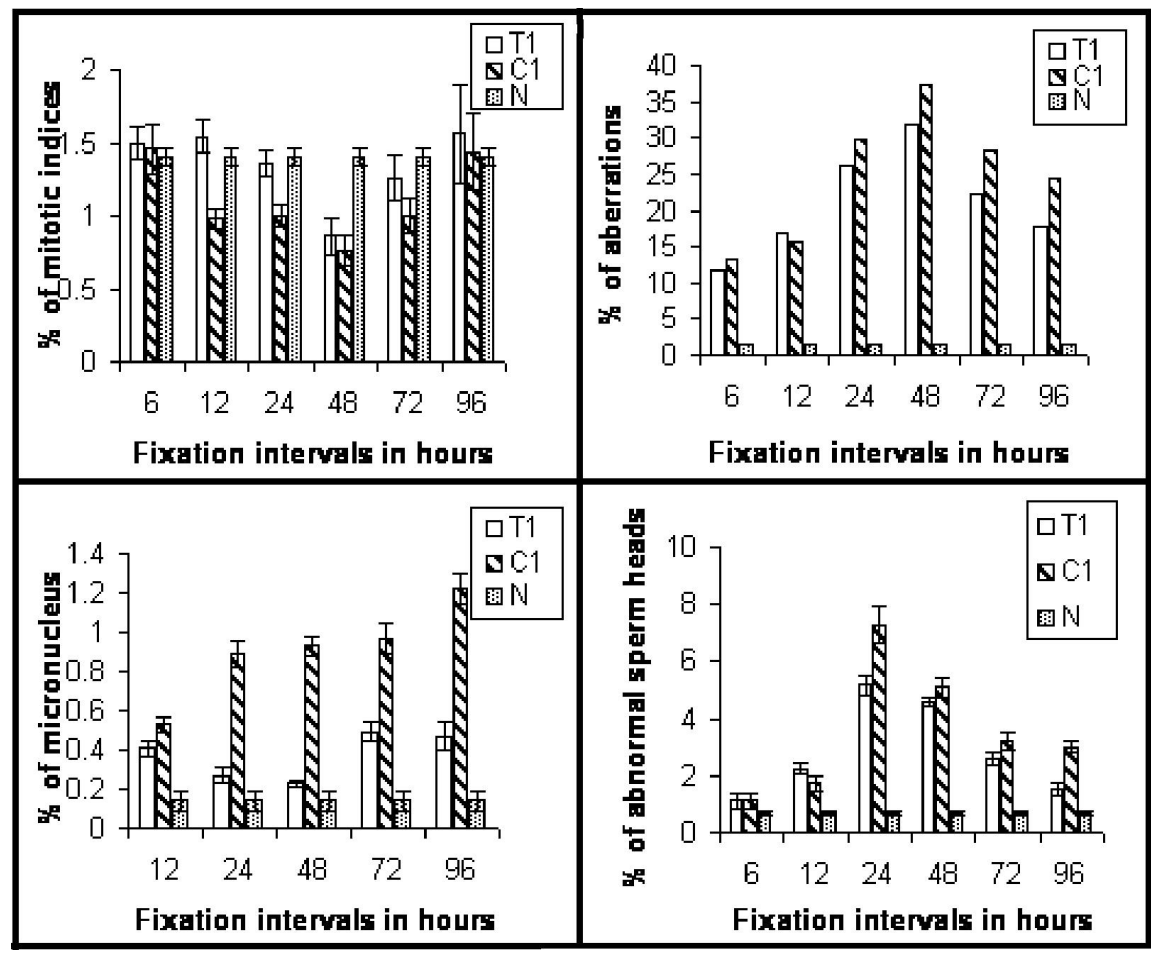

Figure 2. Frequency distribution of MI, CA, MN and SHA in mice at different fixation intervals in mercuric chloride treated mice pre-fed with Merc Sol-30 (T1), alcohol-30 (C1) and normal controls (N).

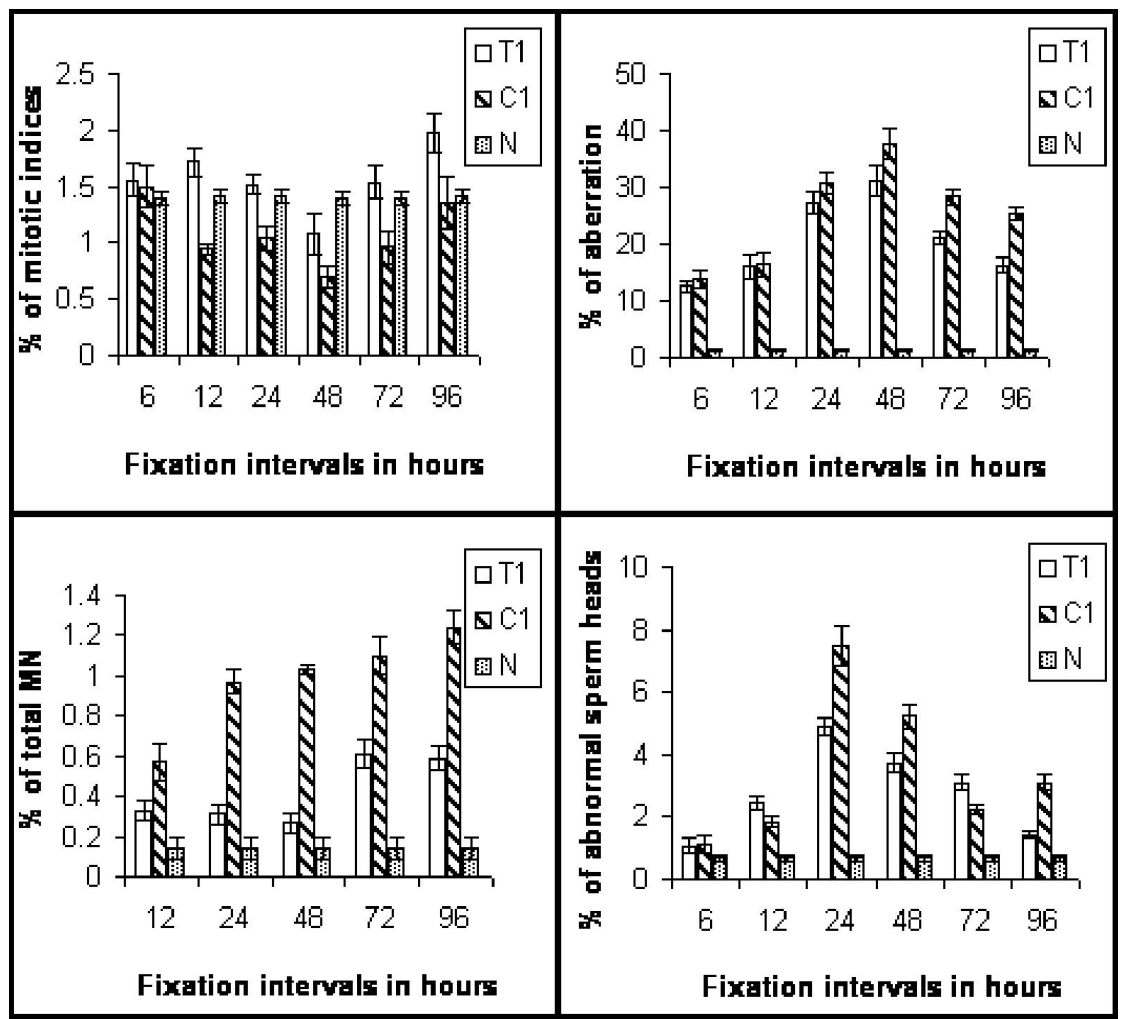

Figure 3. Frequency distribution of MI, CA, MN and SHA in mice at different fixation intervals in mercuric chloride treated mice pre-fed with Merc Sol-200 (T1), alcohol-200 (C1) and normal controls (N). 


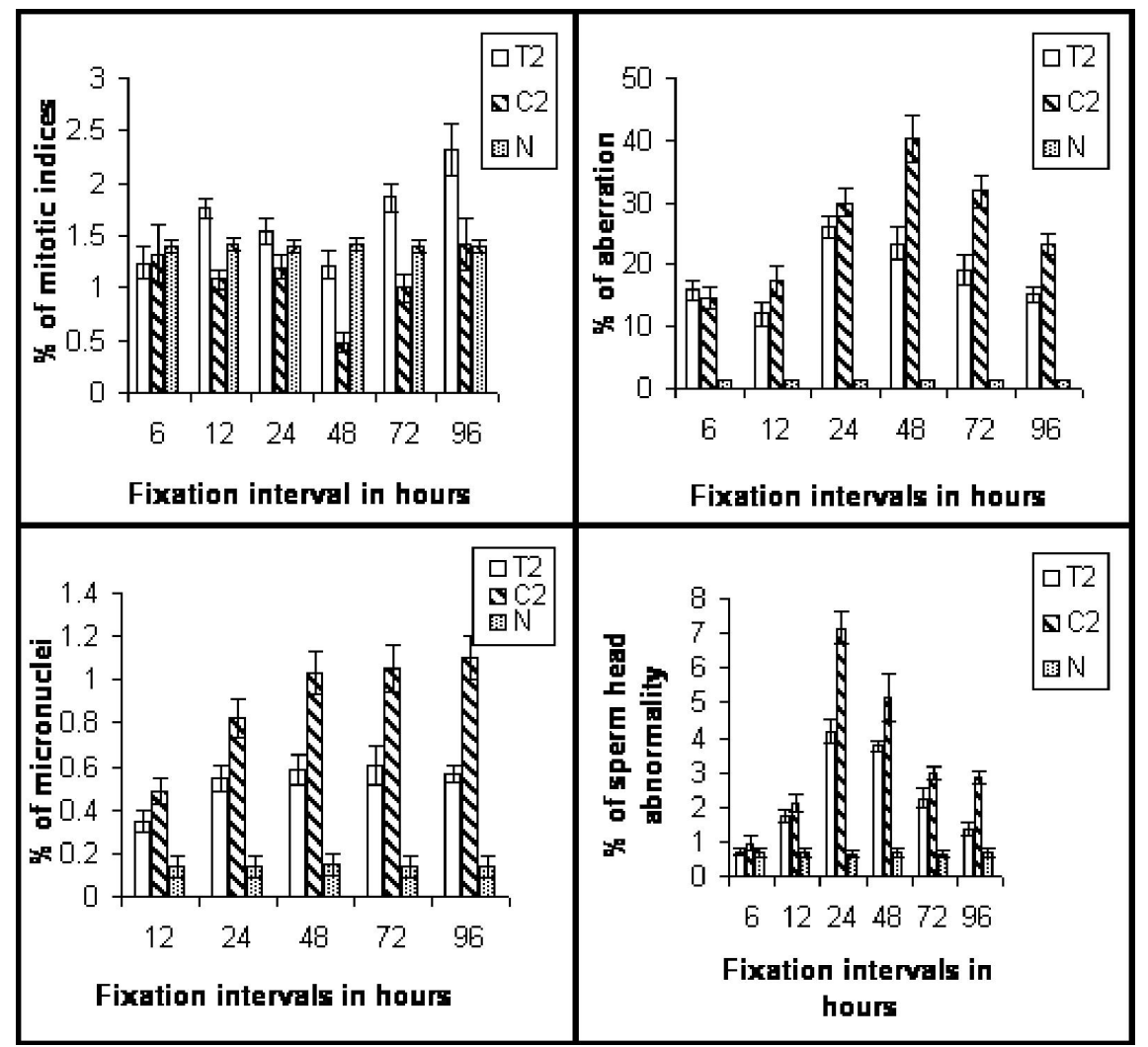

Figure 4. Frequency distribution of MI, CA, MN and SHA in mice at different fixation intervals in mercuric chloride treated mice post-fed with Merc Sol-30 (T2), alcohol-30 (C2) and normal controls (N).

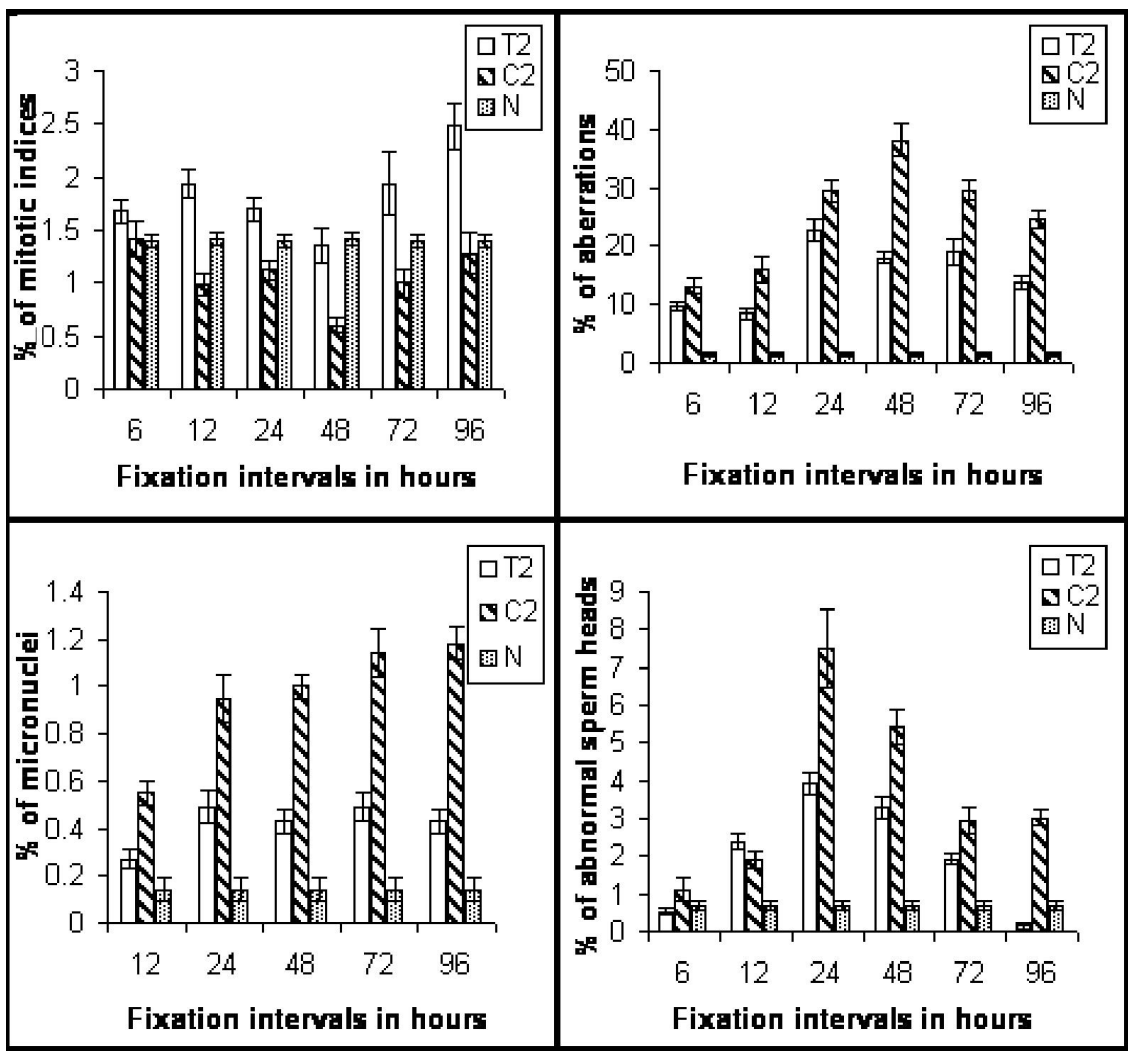

Figure 5. Frequency distribution of MI, CA, MN and SHA in mice at different fixation intervals in mercuric chloride treated mice post-fed with Merc Sol-200 (T2), alcohol-200 (C2) and normal controls (N). 


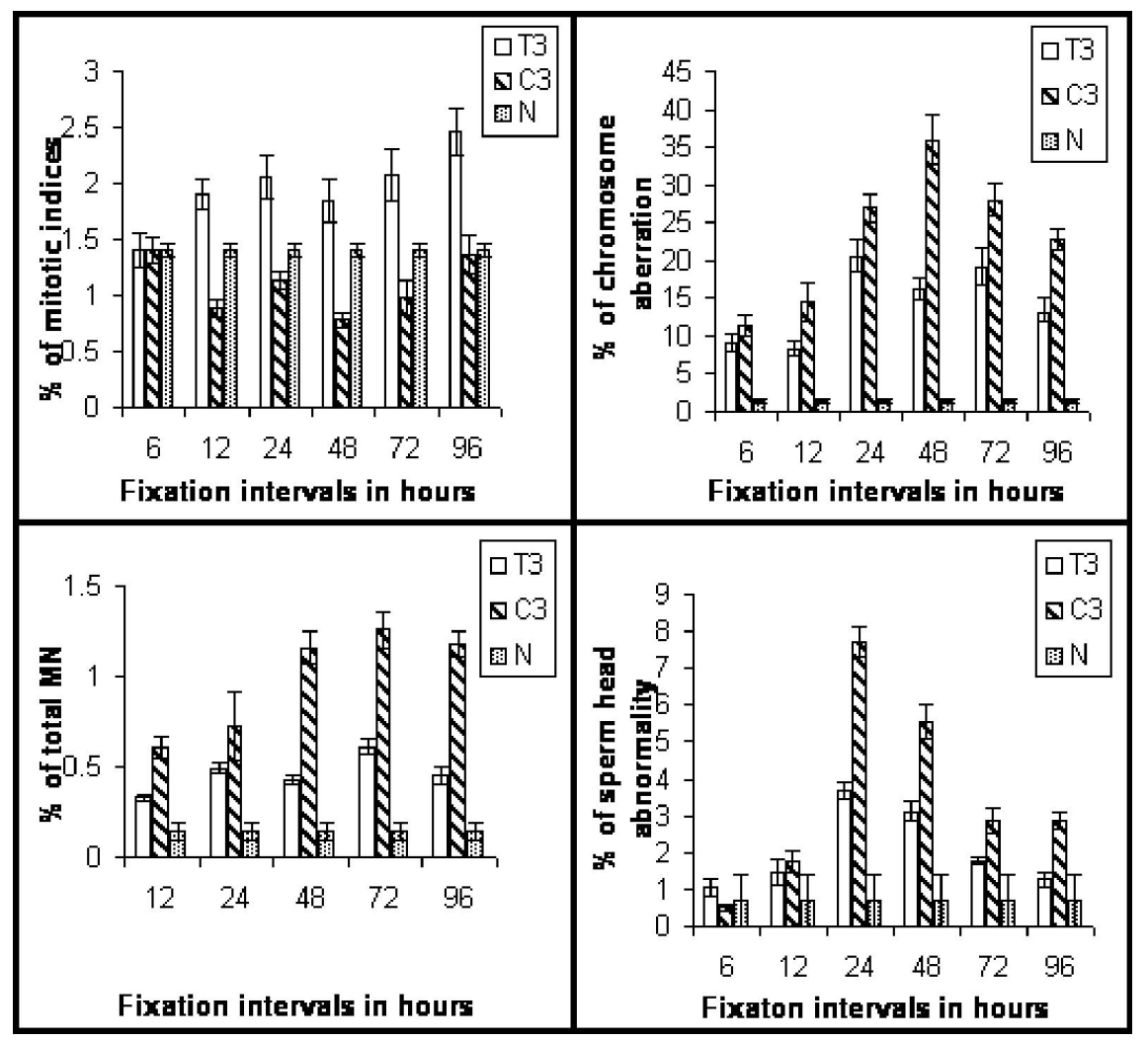

Figure 6. Frequency distribution of MI, CA, MN and SHA in mice at different fixation intervals in mercuric chloride treated mice pre- and post-fed with Merc Sol-30 (T3), alcohol-30 (C3) and normal controls (N).

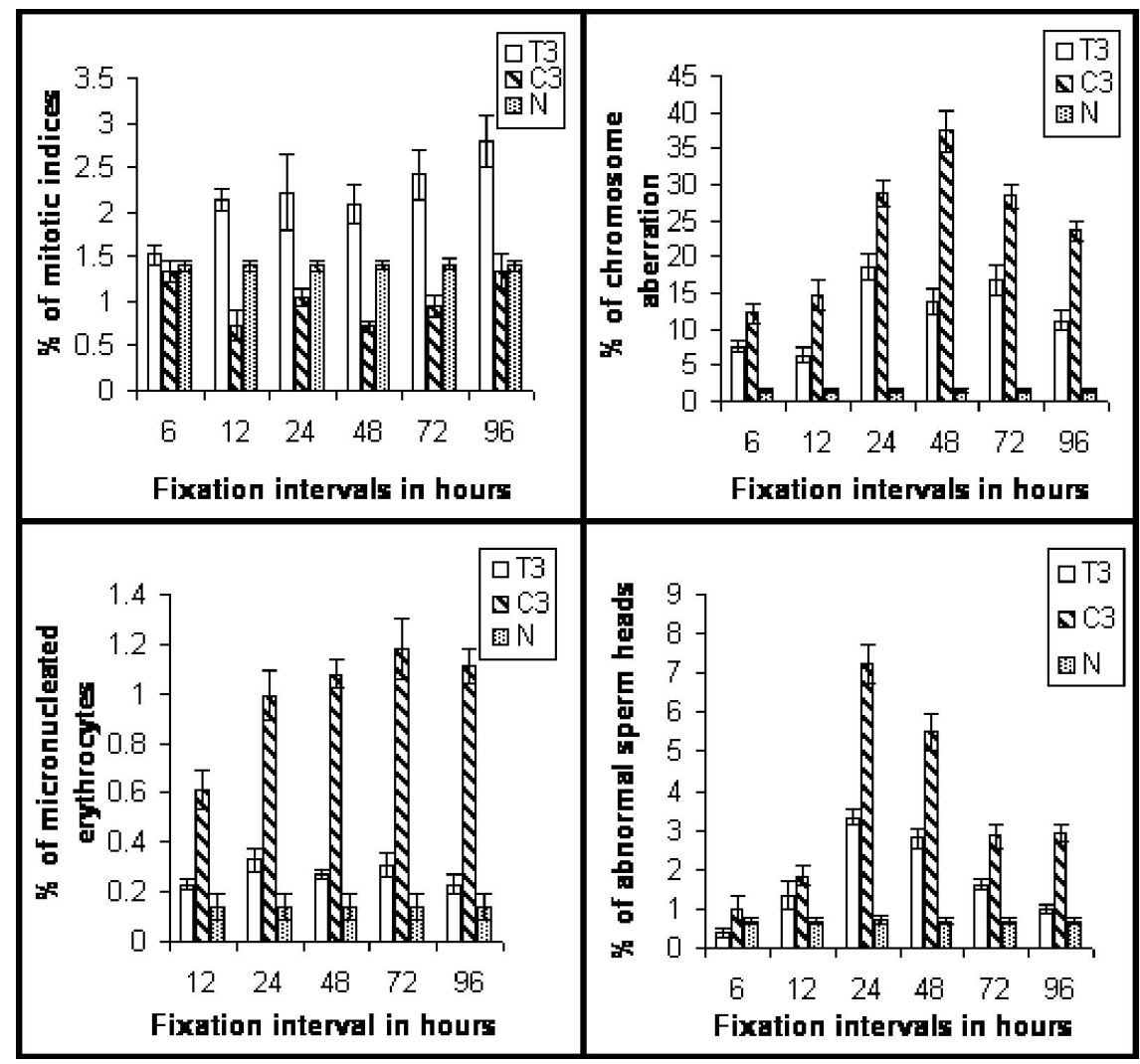

Figure 7. Frequency distribution of MI, CA, MN and SHA in mice at different fixation intervals in mercuric chloride treated mice pre- and post-fed with Merc Sol-200 (T3), alcohol-200 (C3) and normal controls (N). 
(without any materialistic drug ingredient) to enhance the repair process, could possibly be by way of sending/carrying positive signals for faster and effective repair through inducing the right genes or inhibiting others involved in the process of chromosome repair. Incidentally, the repair of protein (including that in sperm head) would also need the corrective action taken by certain genes controlling transcription/translation responsible for maintaining structural integrity of the particular type of protein (in chromosomes or sperm).

Another feature worth noting was that both potencies of Merc Sol appeared to considerably increase the mitotic index of cells, showing direct antagonism (regulatory action) to the mitotic inhibitory effect of mercuric chloride. A similar mitotic enhancement had also been noted in the repair of X-rayinduced chromosome damage by potentized homeopathic drugs $(20,21)$. On the other hand, during artificial induction of hepatocarcinoma in mice by p-DAB, when the mitotic index was becoming increasingly enhanced (prior to tumor formation), a homeopathic drug, Chelidonium, combated it by effectively reducing the divisional activity of hepatocytes (22). Thus, one of the pathways through which the drugs appeared to work was apparently by inducing or inhibiting (i.e. natural regulation) divisional activities of the cells involved. In the present study, more divisional activity was necessary to replenish the cells that might have been lost owing to the clastogenic and mitotoxic effects of mercuric chloride. Incidentally, the cell cycle progression in all living organisms is strictly under genetic control. For a cell to progress through a cell cycle, phosphorylation (by several kinases, mainly products of cdc- 2 genes) and dephosphorylation (by phosphatases, mainly products of cdc- 25 genes) of substrates are the basic requirements $(18,19)$ with the active involvement of several other genes like p-34, p-53, p-21 and some proto-oncogenes (e.g. c-mos) in the process. Thus, the ability of the potentized homeopathic drug to modulate cell cycles could be explained by assuming that the homeopathic drug actually had a regulatory role on the expression of some relevant genes, possibly through a signal transduction mechanism in a bid to step up the recovery process. Thus, the administration of the ultra-diluted homeopathic drug was found not only to reduce the mercuric chloride-induced genotoxicity (Merc Sol-200 showing slightly more pronounced effects), but the results of the present study would also lend support to the contention that one way through which the potentized homeopathic drugs act could indeed be by way of regulating expression of certain genes $(8,23,24)$ and that the principle of 'like cures like' also holds true in the present case, as shown convincingly in the case of Arsenicum album against arsenic intoxication (8).

\section{References}

1. Mitra K, Kundu SN, Khuda Bukhsh AR. Efficacy of a potentized homeopathic drug (Arsenicum album-30) in reducing toxic effects produced by arsenic trioxide in mice: I. On rate of accumulation of arsenic in certain organs. Comp Ther Med 1998;6:178-84.

2. Mitra K, Kundu SN, Khuda Bukhsh AR. Efficacy of a potentized homeopathic drug (Arsenicum album-30) in reducing toxic effects produced by arsenic trioxide in mice: II. On alteration of body weight, tissue weight and total protein. Comp Ther Med 1999;7:24-34.

3. Datta S, Mallick P, Khuda-Bukhsh AR. Efficacy of a potentized homeopathic drug (Arsenic Album-30) in reducing genotoxic effects produced by arsenic trioxide in mice: Comparative studies of pre-, post- and combined pre-and post-oral administration and comparative efficacy of two microdoses. Comp Ther Med 1999;7:62-75.

4. Datta S, Mallick P, Khuda-Bukhsh AR. Efficacy of a potentized homeopathic drug (Arsenic Album-30) in reducing genotoxic effects produced by arsenic trioxide in mice: II. Comparative efficacy of an antibiotic, actinomycin $\mathrm{D}$ alone and in combination with either of two microdoses. Comp Ther Med 1999;7:156-63.

5. Kundu SN, Mitra K, Khuda-Bukhsh AR. Efficacy of potentized homeopathic drug (Arsenicum Album-30) in reducing genotoxic effects produced by arsenic trioxide in mice: III Enzymatic changes and recovery of tissue damage in liver. Comp Ther Med 2000;8:76-81.

6. Kundu SN, Mitra K, Khuda Bukhsh AR. Efficacy of a potentized homeopathic drug (Arsenicum-Album-30) in reducing cytotoxic effects produced by arsenic trioxide in mice: IV. Pathological changes, protein profiles, and content of DNA and RNA. Comp Ther Med 2000;8:157-65.

7. Khuda-Bukhsh AR. The efficacy of potentized homeopathic drug in combating arsenic poisoning a suggestive scientific probe. In: Manna GK, Roy SC (editors), Perspectives of Cytology and Genetics. AICCG Publishers, 2001;10:231-239.

8. Mallick P, Chakrabarti (Mallick) J, Guha B, Khuda-Bukhsh AR. Ameliorating effect of microdoses of a potentized homeopathic drug, Arsenicum Album, on arsenic-induced toxicity in mice. BMC Complemen Altern Med 2003;3:7-16.

9. Hammond PB, Foulkes EC. Metal ion toxicity in man and animals. In: Sigel H (editor), Metal ions in biological systems, 1986, pp. 157-200.

10. Das SK, Sharma A, Talukdar G. Effects of mercury on cellular systems in mammals-A review. The Nucleus 1982;25:193-230.

11. Alexidis AN, Rekka KA, Kourocenakis PN. Influence of mercury and cadmium intoxication on hepatic microsomal CYP2E and CYP3A subfamilies. Mol Pathol Pharmacol 1994;85:67-72.

12. Ramel C. Genetic effects of organic mercury compounds. I. Cytological investigation on allium roots. Hereditas 1969;61:208-30.

13. Ramel C. Genetic effects. In: Friberg L, Vostal J (editors), Mercury in the Environment. OH: Chemical Rubber Publishers, 1972, pp. 169-181.

14. Beattie JH, Marion M, Schmit DP, Denizeau F. The cytotoxic effects of cadmium chloride and mercuric chloride mixtures in rat primary hepatocyte cultures. Toxicol 1990;62:161-73.

15. Wyrobek AJ, Watchmaker G, Gordon L. Sperm morphology testing in mice. In: Kilbey BJ, Legator M, Nichols W, Ramel C (editors), Handbook of Mutagenecity Test Procedures. Amsterdam: Elsevier Science, 1984, pp. 733-50.

16. Kato R. Chromosome breakages associated with organic mercury in Chinese hamster cells in vitro. Mutat Res 1976;38:340-1.

17. Das SK, Talukdar G, Sharma A. Effect of mercuric chloride on rat DNA and RNA. In: Manna GK, Sinha U (editors), Perspectives of Cytology and Genetics. AICCG Publishers, 1984, pp. 383-388.

18. Lewin B. Genes V. Oxford: Oxford University Press, 1994.

19. Cooper GM. The Cell: A Molecular Approach. Washington, DC: ASM Press, Oxford: Oxford University Press, 1997.

20. Khuda Bukhsh AR, Banik S. Assessment of cytogenetical damages in $\mathrm{X}$-irradiated mice and their alterations by oral administrations of a potentized homeopathic drug, Ginseng-200. Berlin J Res Hom 1991;1:254-63.

21. Khuda Bukhsh AR, Maity S. Alteration of cytogenetical effects by oral administration of a homeopathic drug, Ruta graveolens in mice exposed to sub lethal X-irradiation. Berlin J Res Hom 1990;1:264-74.

22. Biswas SJ, Khuda-Bukhsh AR. Effect of a homeopathic drug, Chelidonium, in amelioration of p-DAB induced hepatocarcinogenesis in mice. BMC Complemen Altern Med 2002;2:1-16.

23. Khuda Bukhsh AR. Potentized homeopathic drugs act through regulation of gene expression: a hypothesis to explain their mechanism and pathways of action in vivo. Comp Ther Med 1997;5:43-6.

24. Khuda Bukhsh AR. Towards understanding molecular mechanisms of action of homeopathic drugs: An overview. Mol Cell Biochem $2003 ; 253: 339-45$.

Received 17 November 2003; accepted 13 June, 2004 


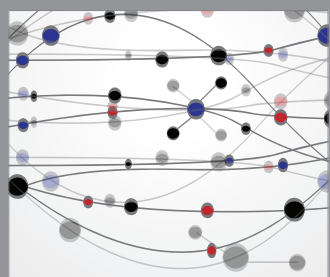

The Scientific World Journal
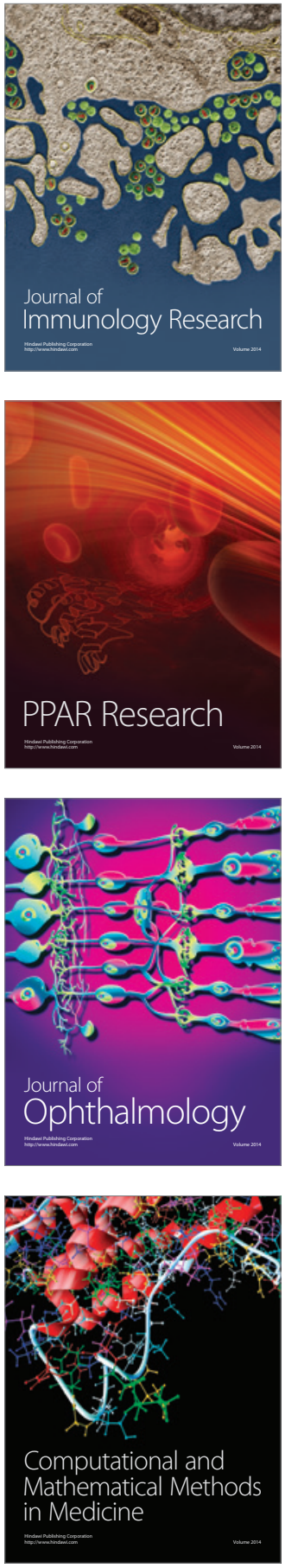

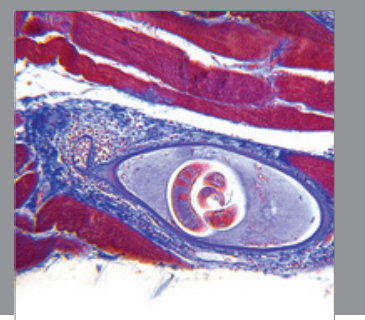

Gastroenterology

Research and Practice
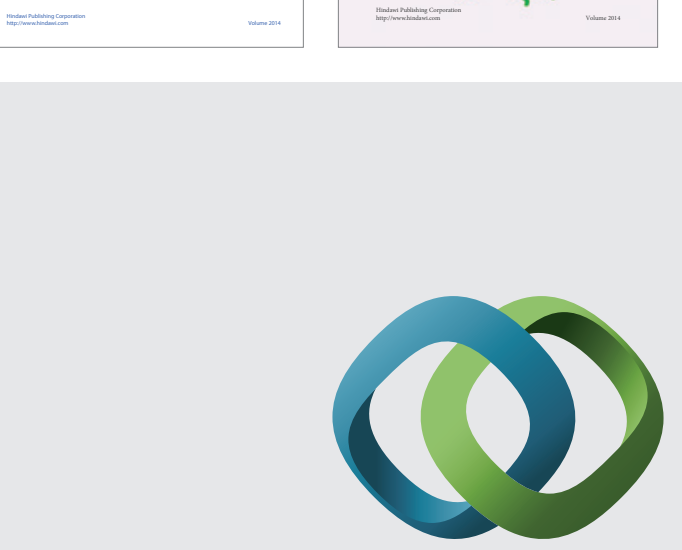

\section{Hindawi}

Submit your manuscripts at

http://www.hindawi.com
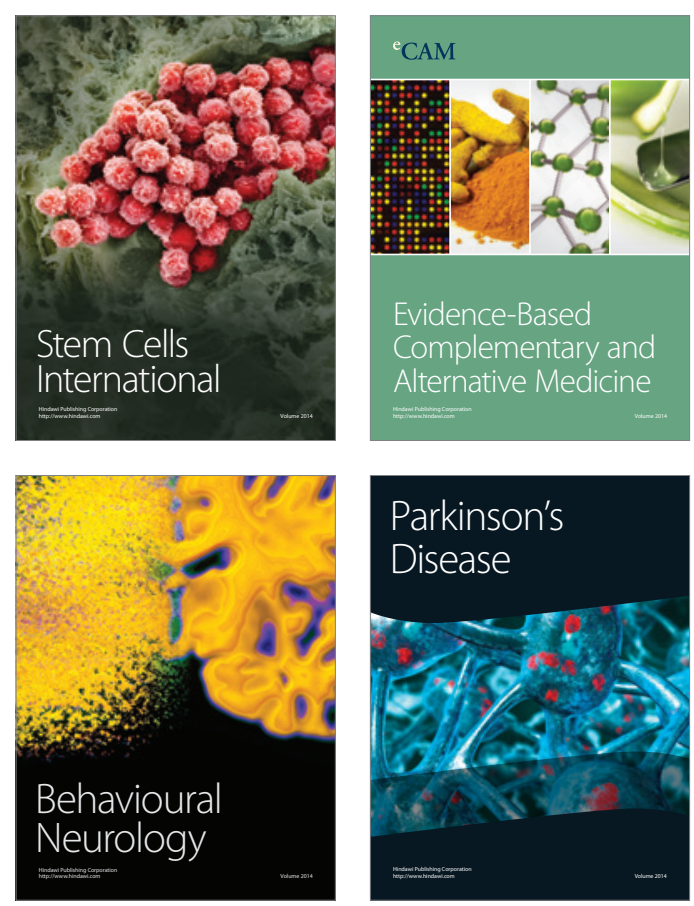

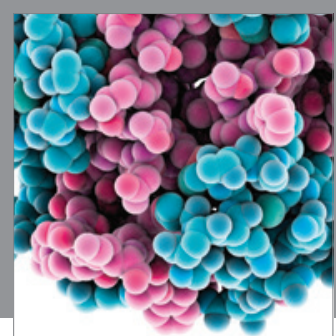

Journal of
Diabetes Research

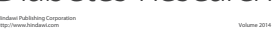

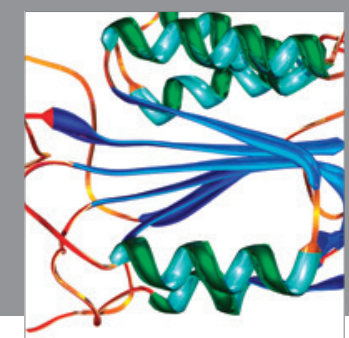

Disease Markers
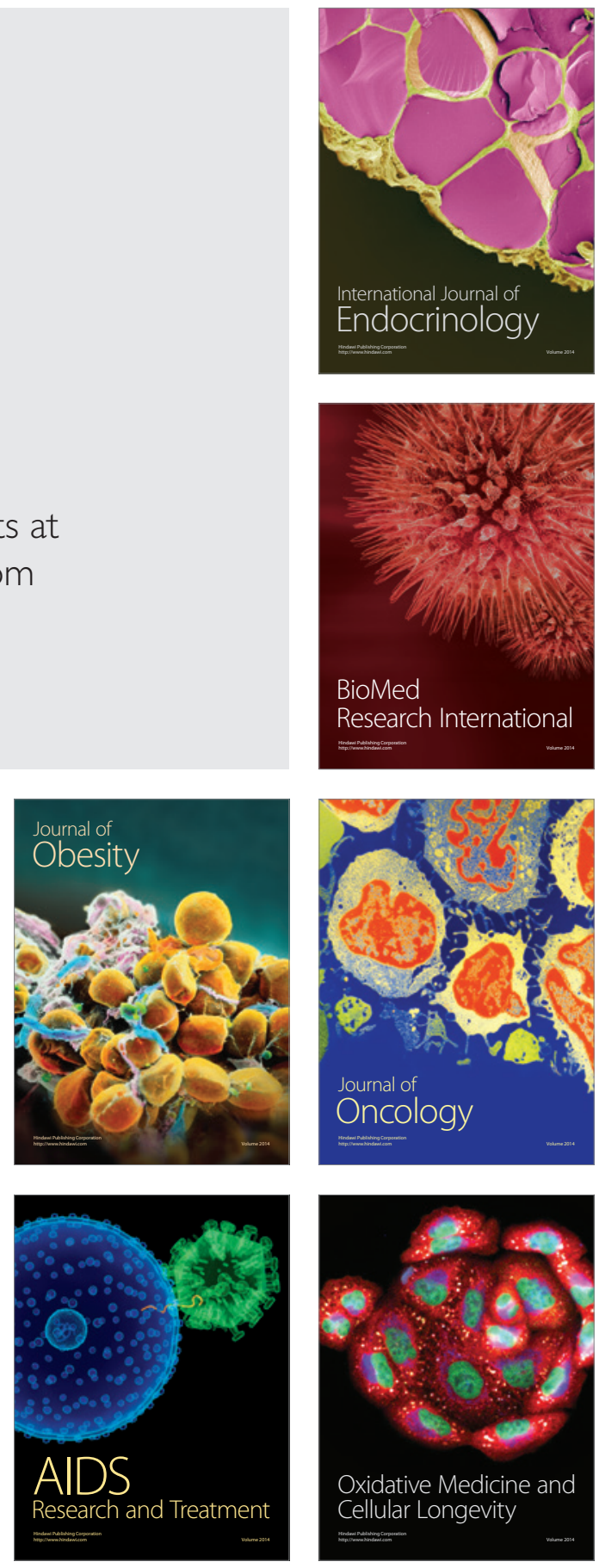